\title{
Asia-Pacific Journal of Health Management \\ DOES INTEGRATED HEALTHCARE SYSTEM REDUCE THE COST OF QUALITY OF CARE FOR OLDER PEOPLE? A SCOPING REVIEW
}

\author{
Mohammad Shamsal Islam', Reza Majdzadeh2, Abul Hasnat Golam Quddus3, Mahfuz \\ Ashraf. 4.5
}

1. Dr. Ahmadur Rahman Research Centre, University of Chittagong, Bangladesh.

2. Knowledge Utilization Research Center, Center for Community-Based Participatory-Research, School of Public health, Tehran University of Medical Sciences, Iran

3. Dr. Ahmadur Rahman Research Centre, University of Chittagong, Bangladesh

4. WHO Centre - University of New South Wales, Sydney, Australia

5. Crown Institute of Higher Education, Sydney, Australia

Correspondence: msislam009@gmail.com

\section{ABSTRACT}

This study provides a summary of published reviews of academic literature on the cost-effectiveness and quality outcomes of integrated healthcare approaches for the older people of in Australia. the available literature which was published in English between January 2001 and July 2017 was were retrieved from the search results in eight highly resourceful journal databases using the specific terms. The majority of the studies reported limited information about the cost intervention and quality of outcomes. The benefits of integrated healthcare included patients' satisfaction, reduction of costs and increasing quality of care. However, the evidence of reduction of cost is varying with the different settings. The home and community-based healthcare for older people has attracted much attention in the past decades in Australia and many researches have been done on it. The majority of the studies focused on defined problems of healthcare service and outcomes but did not incorporate the priorities of cost-effectiveness or quality of care. Practitioners are interested in understanding how the integrated health care approach is achieved and to examine the reduction of cost and quality of outcomes.

\section{KEYWORDS}

aged care, cost-effectiveness, game-changer, integrated care, Australia.

\section{INTRODUCTION}

Australia, just like many western countries, has an ageing population and it is the key driver to change the Australian demographic features. In 2015, the Australia's population aged between 65-84 and 85 years and above was approximately $13 \%$ and $2 \%$ respectively. The $65-84$ years' cohorts are projected to be approximately $18 \%$ (8.9 million) and the 85 years and over to be approximately $5 \%$ by 2054 55. [1] The old people group are the main client of health sector for having complex and chronic conditions. The sharp rise of old people is apparently the "game-changer" in the healthcare sector of Australia.

Around two-thirds of the people above 75 years have at least five chronic long-term health conditions [2] such as Dementia, Diabetes, Depression, Hypertension and Arthritis. Dementia- self-reported mobility problems increase with age affecting most women over 80. [3 4 5] The expenditure on aged services is likely to almost double for the government of Australia. [6] Therefore, exerts pressure on planning, policy and finances of aged care sector. [7] Approximately a quarter of the total spending is directed towards health, age-related pensions and aged care, and it is likely to be halved by 2049-50.[8] The health expenditure in Australia was estimated to be ' $\$ 140$ ' billion in the year 2011-2012, compared to $\$ 133$ billion in the year 2010-11 
and $\$ 83$ billion in the 2001-02. The trends of health spending are relatively even more among hospitals (about $\$ 53.5$ billion) and primary health care (about $\$ 50.6$ billion). [9] Four key factors are contributing to fast-rising health care costs in Australia: population growth, ageing, new technologies and treatment, and experiment in health

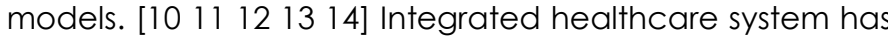
consistently been reviewed or implemented in developed countries to address these challenges and reduce the gaps between costs and quality outcomes. [15, 16] This study highlights the benefits of the integrated healthcare which the Australian government may incorporate in the national policy to reduce costs of quality of care for older people.

\section{METHODS}

Synthesizing health policy and systems evidence has been recognized as a critical tool to support policy decisions and produce guidance for the health systems following by PRISMA Scoping Review (SCR) guidelines since 2012. A scoping review guided by the preferred reporting items for synthesizing research evidence $[17,18]$ was undertaken using eight major online databases: Our Scoping Review mainly focuses on the recent (2001-2017) peer-reviewed articles and reports that might produce empirical evidence on the integrated healthcare. Techniques of conducting Scoping Review are selecting sources and keywords, combining the most promising strings of keywords using logical operators, identifying search areas for articles and reports and executing the search process to identify relevant empirical studies through screening based on specific inclusion and exclusion criteria. [19 2021 l $^{\prime}$ We used recently published SCR techniques [22 23] in our review that included three steps: (a) exploring for the initial list of studies, (b) topicality of evaluation, and (c) extraction and analysis of data. The search process was executed on 8 journals and reports website presented in Appendix- 1 . Finally, we used framework to find the clusters according to the similarity of most used words and phrases. [24] There are numerous studies on non-reviewed publications on the subject, including white papers and reports from different organizations. Although these documents have not been independently evaluated through peer-review processes, we believe that these sources can provide valuable insights.

\section{a) Exploring for the initial list of studies}

We used the following keywords to query each database so that search result would issue articles and reports containing the words 'integrated healthcare' along with "costs" and "quality" and costs-effective and quality care, costs and quality outcomes, etc. Eight online databases were searched for articles and reports published from January 2001 to July 2017 to find the initial list of relevant articles and reports. The search query returned a total of 109910 articles and reports on integrated healthcare for older people and finally returned 3246.

\section{b) Topicality of evaluation}

In the second step, we select relevant articles and reports from the initial list and excluded the irrelevant articles and reports by reading the papers' titles, keywords, abstracts and full text. Reports and articles that were excluded from the lists to follows the exclusion criteria (figure 1).

\section{c) Extraction and analysis of data}

In the extraction stage reviewers considered key details to further identify articles and reports based on inclusion and exclusion strategy for identifying topical studies, [23 24] including deleting similar papers, publication year, geographical area, types of communication, outcome measures, and results. As a result, 25 articles and reports were selected for further analysis. Figure 1 below shows the results of search and selection of studies with exclusion steps.

\section{ETHICAL APPROVAL:}

Ethical approval is required for conduct of research on human subjects and our research work is limited only on published materials in the public domain and for these reasons we have ignored the necessity of ethical approval.

\section{RESULTS}

We have searched a total of 3246 references across the eight databases, and after careful consideration of duplications, 21 articles and 4 reports were identified as eligible for inclusion. During the review of the full-text articles, we have selected twelve systematic reviews, [2536] four systematic and meta-analyses [37-40] and a review of the literature resulted in 3 additional sources [41-43] for further assessment. One review presented an update about economic outcomes [44] and we have included the earlier review only. 


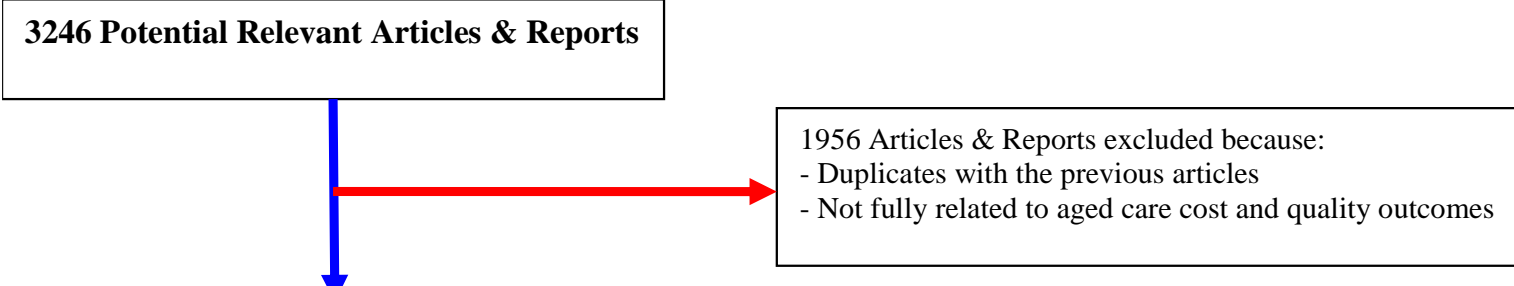

1290 Potential Relevant Articles \& Reports

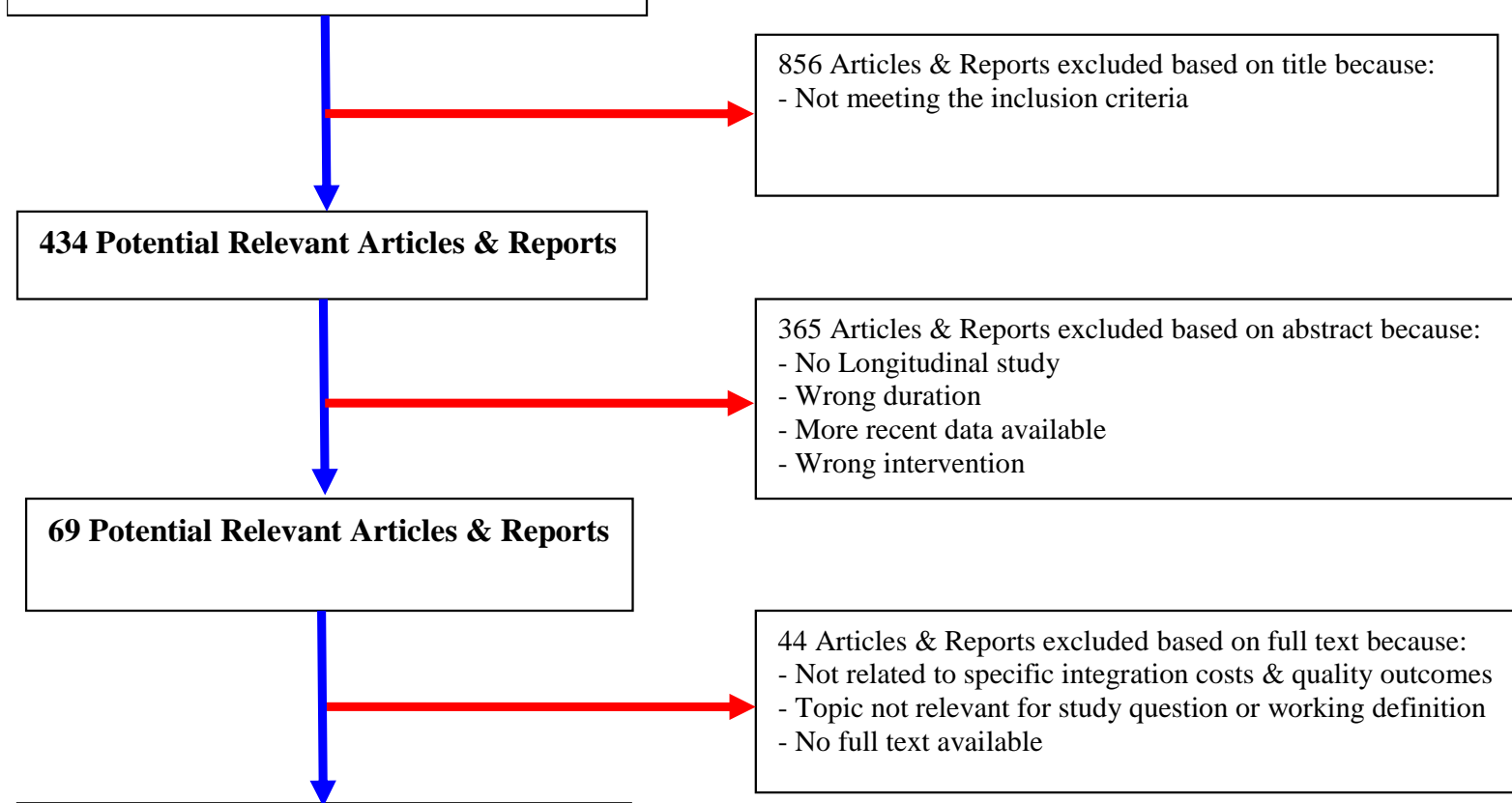

25 Potential Relevant Articles \& Reports

\section{DISCUSSION}

In the current report we have explored into a very recent academic literature forcusing on integrated care for aged people and followed very specific key words on integrated healthcare and quality outcomes. The first limitation of our study is that it includes the reviews only and we assessed the cost-effectiveness, quality outcomes and service delivery on the basis of original studies in individual reviews. Although, the existing systematic reviews and metaanalysis imply that, most of our reviewed articles and reports were the original studies. We have discussed above how reviews tended to report qualitatively on selected measures such as cost-effectiveness, quality outcomes and service delivery. Final limitation is that the majority of the studies focused on the defined problems of healthcare service and outcomes but did not incorporate the priorities of cost-effectiveness or quality of care accurately. There are wide range of definitions and interpretations of the concept of integrated healthcare system and delivery services: wide range of very varied interventions and care approaches (for instance, case management). Integrated care is an interdisciplinary healthcare approach that addressed the needs of patients. The World Health Organization defines integrated healthcare as 'the organization and management of health services' in order that people get the care they have, once they would like it, when they need it, in ways that are user-friendly, attain the specified results and provide value for money. [44] Integration means improving the outcomes through coordination of services along with continuum of care. The healthcare services for older people of Australia is complex, it involves many funders and healthcare providers. Agerelated chronic conditions have an impact on the 
expenditure, healthcare services, and pharmaceuticals. The total health expenditure has increased to approximately $5.4 \%$ per year over the last decade, while GDP has been increasing at a slower rate of $3.1 \%$ per year. (Table 1 \& 2).

From the table one we have observed that service delivery efficiency and effectiveness increases with coordinated primary care, especially for aged care at community setting. It also increases with the: advanced care planning, pain management and palliative care services. These combined increase client satisfactionand reduce emergency department visits and hospital stays. [ 44 45]

The summarized data indicate that waiting time and days of staying at hospital drastically declined in integrated care at both community and hospital settings. These findings suggested that integrated care delivery reduces the cost of care and increases the quality of outcomes. [26 273146 47 48] For instance, table two data show that integrated care reduces the emergency department visits by $20.8 \%$, hospital admissions by $27.9 \%$ and housing staying days by (home care services) 19.2\%. However, these results depend on the level of integration and service delivery. [49 50] The level of integration can be influenced by personalcentered approach, understanding the need of the community, degree of integration, leadership and level of collaboration within the key stakeholders, and effective exchange and utilization of information. [47 48 49] Strongly coordinated care can save between $5-10 \%$ of the costs. The cost of benefits and quality of care depends on relationships between hospital management body and GPs. [48 49] In table two the cost effectiveness section shows that integrated primary care in the appropriate setting can meet up to $90-95 \%$ of the health needs, produce better health outcomes and improved costeffectiveness following the triple aim: better health outcomes, better care, and lower costs. [49 50] Functional integration is more significant than merely structural or financial integration. The majority of studies related to integrated service showed that there were positive effects on quality of care, however, measuring the performance of the health system, cost and quality of outcomes of the system accurately is very difficult. [36] Various studies and evidences have shown that integrated health care contributes to a cost-efficient and quality health system through streamlined care for patients, efficient use of resources, a better cover of patients and improved patient safety.[50]
Evidence have shown that integration of service delivery and minimizing the gap of aged care are crucial in controlling the high expenditure of aged care services. Reviews reveal that fragmented healthcare is struggling with rising costs and poor-quality outcomes while integrated healthcare might be affordable and accessible for older people through reduction in costs of care. [25 33 34] Our review also shows that integrated healthcare is more cost-effective than the current fragmented system across different settings. Integrated patient-centered healthcare saves the state 'Medicare' costs, Pharmacy costs, and general costs. [16] Our reviews have found 4 out of 5 articles reported that integrated care is associated with low cost of care and quality outcomes at different settings. [46 $\left.47 \begin{array}{lll}48 & 49\end{array}\right]$ Integration is challenging, but it extends benefits to patients, caregivers and healthcare providers. Most of the reviewed literature shows that the quality of care is increased with integration of care. The integrated consumer-directed coordinated healthcare and preventive services increase the quality of care at appropriate settings.

\section{CONCLUSIONS}

There may also be a need to rethink our understanding of what integrated care is and it is important to reach a consensus about cost-effectiveness and support financial sustainability for long-lasting change in the way the service delivery in the health and social-care sectors are conducted. The Review findings suggest that integrated healthcare for older people still requires much attention from top-levels to understand how the integrated healthcare approach is achieved and to examine the reduction of cost and quality of outcomes.

\section{ACKNOWLEDGEMENT:}

We would like to acknowledge Professor Yvonne Wells, Head Lincoln Centre for Research on Ageing, Australian Institute for primary Care and Ageing, College of Science, Health and Engineering, La Trobe University for her comments on the very initial version. 


\section{References:}

1. Legislated Review of Aged care, Australia Department of Health: Commonwealth of Australia, Canberra ACT 2601, [Cited June 2017.]. Available from URL: http:// agedcare.health.gov.au/aged-carereform

2. The king fund, London. Making best use of the better care fund. Spending to save? [Cited January 2014.]. Available from URL:

http://www.kingsfund.org.uk/sites/files/kf/ field/field_publication_file/making-best-use-of-thebettercare-fund-kingsfund-jan 14.pdf

3. Peninsula College of Medicine and Dentistry Ageing Research Group, UK. Health care quality for an active later life: Improving quality of prevention and treatment through information: England 2005 to 2012. [Cited May 2012.]. Available from URL: http://medicine.exeter.ac.uk/media.

4. Integrated care for older people: Guidelines on community-level interventions to manage declines in intrinsic capacity, WHO. [Cited 2017]. Available from URL:http://www.who.int/iris/bitstream/10665/258981/1/ 9789241550109-eng.pdf? ua

5. Ready for ageing?' Select Committee on Public Service and Demographic Change. UK Parliament report of Session 2012-13, London. [Cited 2013] Available from URL:

https://publications.parliament.uk/pa/ld201213/ldsele ct/ldpublic/140/14003.htm

6. Australia's Demographic Challenges; Department of Communications, Information Technology and the Arts, Canberra ACT 2601 [Cited 2004.]. Available from URL http://www.dcita.gov.au/cca.

7. Fifth report on the funding and financing of the Aged Care sector'; Aged care financing authority, Canberra ACT 2017 [Cited 2017]: Available at https://agedcare.health.gov.au/sites/g/files/net1 426/f Ldocuments/08 2016/2016 report

8. Fourth report on the funding and financing of the Aged Care sector'; Canberra ACT 2014: Available at https://agedcare.health.gov.au/sites/g/files/net1426/f Ldocuments/08 2016/2016 report

9. Inaugural report on the funding and financing of the Aged Care Sector', June 2013, Canberra. Australian Government, Aged care financing authority. [Cited 2013]. Available at https://agedcare.health.gov.au/sites/g/files/net1426/f /documents/08_2013/2013_report

10. Harris, A, McGillis $L H$. 'Evidence to inform staff mix decision-making: A focused literature review', [Cited 2012] Available at

https://www.researchgate.net/publication/293654178 Evidence to Inform Staff Mix DecisionMaking_A_Focused_Literature_Review

11. Hixon, L, Savage E, Chenoweth L. 'Environmental and organizational factors associated with integrated aged care delivery structures in New South Wales',

2012; available at

https://www.ageing.ox.ac.uk/people/view/12

12. Lewin, $G$, Burton $E$, Sparrow $P$, Carroll M, Kendig $H$. 'Development of a community care research agenda for Australia', Australasian Journal on Ageing, vol 31, issue 1, Wiley-Blackwell Publishing Asia, 2011 pp. 37-40 available at

http://journals.sagepub.com/doi/abs/10.1177/1468017 $\underline{316654346}$

13. A good life in old age? Monitoring and improving quality in long-term care', OECD Health Policy Studies, OECD [Cited 2013]. Available at http://www.oecd.org/els/health-systems/a-good-lifein-old-age-9789264194564-en.htm

14. Delivering Effective, Integrated System of Primary and Community Care. Government of British Columbia, Ministry of Health, 2015a[Cited 2015] Available at

http://www.health.gov.bc.ca/library/publications/yea r/2015/primary-and-community-care-po

15. Daniels A S, Adams N, Carroll C, Beinecke R H. 'A conceptual model for behavioural health and primary care integration: Emerging challenges and strategies for improving international mental health services'. International Journal of Mental Health, 38(1), 100-112, 2009; doi: 10.2753/IMH0020-7411380109, available at https://www.integration.samhsa.gov/workforce/Integr ation Competencies Final.pdf

16. Blount A, Ed D. 'integrated primary care:

Organizing the evidence. Families, Systems, \& Health', 21,121-134, Department of Family Medicine and Community Health, UMass Memorial Health Care, 2003; http://www.apa.org/journals/fsh.html 
17. Arksey H, O'Malley L. Scoping studies: Towards a Methodological Framework. International journal of social research methodology. 2005; 8(1): 19-32.

18. Levac D, Colquhoun H, O'Brien KK. Scoping studies: advancing the methodology. Implement Sci 2010; 5:69 doi:10.1186/1748-5908-5-69

19. Stelfox HT, Perrier L, Straus SE, et al. Identifying intensive care unit discharge planning tools: protocol for a scoping review. BMJ Open 2013;3: e002653 doi:10.1136/bmjopen-2013-002653

20. Daudt HM, Van Mossel C, Scott SJ. Enhancing the scoping study methodology: a large, Inter professional team's experience with Arksey and O'Malley's framework. BMC medical research methodology. 2013; 13(1):48

21. Tricco AC, Lillie E, Zarin W, et al. A scoping review on the conduct and reporting of scoping reviews. BMC Med Res Methodol 2016; 16:15 doi:10.1186/s12874-016-0116-4

22. Moher D, Schulz KF, Simera I, Altman DG. Guidance for developers of health research reporting guidelines. PLoS Med. 2010; 7(2): e1000217

23. Diamond IR, Grant RC, Feldman BM, et al. Defining consensus: a systematic review recommends methodologic criteria for reporting of Delphi studies. JCE 2014; 67(4):401-409

23. Ageism and Age Discrimination in Secondary Health Care in the United Kingdom: Centre for Policy on Ageing, [Cited 2009]. Available at http://www.cpa.org.uk/information/reviews/CPAageism and age discrimination in sec

24. Chaudhry B, Wang J, Wu S, Maglione M, Mojica W, Roth E, Shekelle P G. 'Systematic review: impact of health information technology on quality, efficiency, and costs of medical care. Annals of internal medicine'; 2006, 144(10), 742-752.

25. Chiu WK, Newcomer R. A systematic review of nurse-assisted case management to improve hospital discharge transition outcomes for the elderly. Professional Case Management, 2007; 12(6):330-336; quiz 37-38;

26. Althaus F et al. Effectiveness of interventions targeting frequent users of emergency departments: a systematic review. Annals of Emergency Medicine, 2011 ; 58(1):41-52, e42; available URL from https://www.ncbi.nlm.nih.gov/pubmed/21689565.
27. Gilbody S, Bower P, Whitty P. Costs and consequences of enhanced primary care for depression: systematic review of randomised economic evaluations. British Journal of Psychiatry, 189:297-308. Glasby J, Dickinson H, Peck E (2006). Guest editorial: partnership working in health and social care. Health and Social Care in the Community, 2006; 14:373-374;

28. Brink-Huis A, van Achterberg T, Schoonhoven L. Pain management: a review of organisation models with integrated processes for the management of pain in adult cancer patients. Journal of Clinical Nursing, 2008; 17(15):1986-2000;

29. Smith L, Newton R. Systematic review of case management. Australian and New Zealand Journal of Psychiatry, 2007; 41 (1):2-9; Available URL from https://www.tandfonline.com/doi/abs/10.1080/000486 70601039831

30. Van Steenbergen-Weijenburg KM et al. Costeffectiveness of collaborative care for the treatment of major depressive disorder in primary care. A systematic review. BMC Health Services Research, 2010; 10:19;

31. De Bruin S et al. Impact of disease management programs on healthcare expenditures for patients with diabetes, depression, heart failure or chronic obstructive pulmonary disease: a systematic review of the literature. Health Policy, 2011; 101:105-121.

32. Smith $S$ et al. Interventions for improving outcomes in patients with multimorbidity in primary care and community settings. Cochrane Database of Systematic Reviews, 2012; 18(4):CD006560.

33. Tranfield D R, Denyer D, Smart P. 'Towards a methodology for developing evidence-informed management knowledge by means of systematic review'. British journal of management, 2003; 14, 207 222.

34. Béland $F$, Bergman $H$, Lebel $P$, Clarfield, $M$. 'A System of Integrated Care for Older Persons with Disabilities in Canada: Results from a Randomized Control Trial.' The Journals of Gerontology; Series A: Biological Sciences and Medical Sciences, 2006; Vol. 61 A, No. 4: 367-374: available at https://academic.oup.com/biomedgerontology/articl e/61/4/367/607521

35. Bird S, Kurowski W, Dickman G Kronberg I. 'Integrated Care Facilitation for Older Patients with Complex Needs Reduces Hospital Demand.' 
Australian Health Review, 2007; Vol. 31, No. 3: 451-461: available at

https://www.ncbi.nlm.nih.gov/pubmed/17669069

36. Shepperd $\mathrm{S}$ et al. Avoiding hospital admission through provision of hospital care at home: a systematic review and meta-analysis of individual patient data (brief record). Canadian Medical Association Journal, 2009; 180(2):175-82.

37. Steffen $S$ et al. Discharge planning in mental health care: a systematic review of the recent literature (structured abstract). Acta Psychiatrica Scandinavica, 2009, 120(1):1-9.

38. Tappenden $\mathrm{P}$ et al. The clinical effectiveness and cost-effectiveness of home-based, nurse-led health promotion for older people: a systematic reviewHealth Technology Assessment, 2012; 16(20):1-72.

39. Langhorne P et al. Early supported discharge services for stroke patients: a meta-analysis of individual patients' data. Lancet, 2005; 365:501-506.

40. Fulop N, Mowlem A, Edwards N (2005). Building integrated care: lessons from the UK and elsewhere. London, The NHS Confederation.

41. Delnoij D, Klazinga N, Glasgow I. Integrated care in an international perspective. International Journal of Integrated Care, 2002; 2:1-4.

42. Ahgren B, Axelsson R. Evaluating integrated health care: a model for measurement. International Journal of Integrated Care, 2005; 5:1-9.

43. Langhorne P et al. Early supported discharge services for stroke patients: a meta-analysis of individual patients' data. Lancet, 2005; 365:501-506.

44. Esterman AJ, Ben-Tovim DI), The Australian coordinated care trials: success or failure? Med J Aust 2002; 177 (9): 469-470. Published online: 4 November 2002

45. Hébert R, Raîche M, Dubois MF, Gueye NR, Dubuc $\mathrm{N}$, Tousignant $\mathrm{M}$; Impact of PRISMA, a coordinationtype integrated service delivery system for frail older people in Quebec (Canada): A quasi-experimental study; J Gerontol B Psychol Sci Soc Sci. 2010 Jan;65B (1):107-18. doi: 10.1093/geronb/gbp027. Epub 2009 May 4.

46. Nick G Anna D G Anderson W W; Providing integrated care for older people with complex needs Lessons from seven international case studies; The King's Fund 2014
47. Ellen N \& Emma P; What is the evidence on the economic impacts of integrated care? Policy summary II, WHO Regional Offi ce for Europe UN City, Marmorvej 51, DK-2100 Copenhagen $\varnothing$, Denmark, 2014

48. Ouwens $M$ et al. Integrated care programmes for chronically ill patients: a review of systematic reviews. International Journal for Quality in Health Care, 2005, 17:141-146.

49. Hong T C, Shih J C, Hwei J S. 'Integrated Care for the Elderly in the Community' International Journal of Gerontology | December 2008 | Vol 2 | No 4 available at

http://www.sciencedirect.com/science/article/pii/S18 $\underline{73959809700055}$

50. Brown L, Tucker C, Domokos T. 'Evaluating the impact of integrated health and social care teams on older people living in the community' Health Soc Care Community. 2003 Mar; 1 (2):85-94 available at https://www.ncbi.nlm.nih.gov/pubmed/14629210 
TABLE-1 KEY FEATURES OF INTEGRATED CARE APPROACHES (DEFINITION, SERVICE DELIVERY, COST AND QUALITY OUTCOME)

\begin{tabular}{|c|c|c|c|c|c|c|}
\hline \multirow{2}{*}{ Author's } & \multirow{2}{*}{ Title } & \multirow{2}{*}{$\begin{array}{l}\text { Study } \\
\text { design }\end{array}$} & \multirow{2}{*}{$\begin{array}{c}\text { Targeted } \\
\text { populations }\end{array}$} & \multirow{2}{*}{$\begin{array}{l}\text { Definition of } \\
\text { integrated care }\end{array}$} & \multicolumn{2}{|c|}{ Outcome measures } \\
\hline & & & & & $\begin{array}{l}\text { Functional status } \\
\text { and outcomes }\end{array}$ & $\begin{array}{c}\text { Efficacy and client } \\
\text { satisfaction }\end{array}$ \\
\hline $\begin{array}{ll}\text { David } & T \\
(2017)[1] & \end{array}$ & $\begin{array}{l}\text { Legislated } \\
\text { review of } \\
\text { aged care } \\
2017\end{array}$ & $\begin{array}{l}\text { Data gathered } \\
\text { from wide } \\
\text { range of } \\
\text { stakeholders, } \\
\text { including } \\
\text { consumers } \\
\text { and providers. }\end{array}$ & $\begin{array}{lr}\text { Frequent } & \text { service } \\
\text { providers } & \text { and } \\
\text { consumers. } & \end{array}$ & $\begin{array}{l}\text { No explicit definition, } \\
\text { interventions data were } \\
\text { collected from primary } \\
\text { source and workshop. }\end{array}$ & $\begin{array}{l}\text { (i) Support the primary care } \\
\text { system to increase the efficiency } \\
\text { and effectiveness of medical } \\
\text { services. (ii) to improve } \\
\text { coordination of care. (iii) } \\
\text { linkages between aged and } \\
\text { hospital care. }\end{array}$ & $\begin{array}{l}\text { Access to effective end-of-life } \\
\text { care, including advanced care } \\
\text { planning, pain management, } \\
\text { palliative care and family } \\
\text { support. }\end{array}$ \\
\hline $\begin{array}{l}\text { Esterman AJ, } \\
\text { Ben-Tovim } \\
\text { DI } \quad(2002) \\
{[44]}\end{array}$ & $\begin{array}{l}\text { The } \\
\text { Australian } \\
\text { coordinated } \\
\text { care trials: } \\
\text { success or } \\
\text { failure? }\end{array}$ & $\begin{array}{l}\text { Data gathered } \\
\text { from wide } \\
\text { range of } \\
\text { stakeholders } \\
\text { and } \\
\text { consumers }\end{array}$ & $\begin{array}{l}\text { Service providers } \\
\text { and consumers }\end{array}$ & 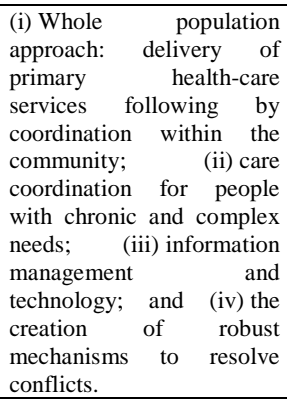 & $\begin{array}{l}\text { (i) Aged people felt supported } \\
\text { and less anxious and GPs were } \\
\text { very satisfied; (ii) Less number } \\
\text { of clients' referrals to } \\
\text { community health services. }\end{array}$ & $\begin{array}{l}\text { Clients' satisfaction was high } \\
\text { and as a result, fewer emergency } \\
\text { department visits and shorter } \\
\text { hospital stays. }\end{array}$ \\
\hline $\begin{array}{l}\text { Hébert R et,al. } \\
\text { (2010) [45] }\end{array}$ & $\begin{array}{l}\text { Impact of } \\
\text { PRISMA, a } \\
\text { coordination- } \\
\text { type } \\
\text { integrated } \\
\text { service } \\
\text { delivery } \\
\text { system for } \\
\text { frail older } \\
\text { people in } \\
\text { Quebec } \\
\text { (Canada): A } \\
\text { quasi- } \\
\text { experimental } \\
\text { study. }\end{array}$ & $\begin{array}{l}\text { Data were } \\
\text { gathered } \\
\text { randomly } \\
\text { using } \\
\text { questionnaires }\end{array}$ & $\begin{array}{l}\text { Service recipients } \\
\text { ( } 75 \text { years or } \\
\text { older) }\end{array}$ & $\begin{array}{l}\text { (i) Coordination between } \\
\text { decision-makers and } \\
\text { managers; (ii) single entry } \\
\text { point to care; (iii) focus on } \\
\text { clients' functional } \\
\text { autonomy. }\end{array}$ & $\begin{array}{l}\text { (i) Increased client satisfaction } \\
\text { and empowerment; (ii) fewer } \\
\text { unmet needs; (iii) better system } \\
\text { performance at no additional } \\
\text { cost. }\end{array}$ & $\begin{array}{l}\text { health services utilization, a } \\
\text { lower number of visits to } \\
\text { emergency rooms and } \\
\text { hospitalizations than expected } \\
\text { was observed in the experimental } \\
\text { cohort }\end{array}$ \\
\hline $\begin{array}{l}\text { Nick G et al. } \\
(2014)[46]\end{array}$ & $\begin{array}{l}\text { Providing } \\
\text { integrated } \\
\text { care for older } \\
\text { people } \\
\text { with complex } \\
\text { needs } \\
\text { Lessons from } \\
\text { seven } \\
\text { international } \\
\text { case studies }\end{array}$ & $\begin{array}{l}\text { Data were } \\
\text { synthesises } \\
\text { from seven } \\
\text { case study } \\
\text { programmes. }\end{array}$ & $\begin{array}{l}\text { Seven countries-- } \\
\text { Australia, } \\
\text { Canada, the } \\
\text { Netherlands, New } \\
\text { Zealand, Sweden, } \\
\text { the United } \\
\text { Kingdom and the } \\
\text { United States. }\end{array}$ & $\begin{array}{l}\text { (i) Integration means } \\
\text { vertical integration } \\
\text { (ii) people in the } \\
\text { community with complex } \\
\text { needs targeted; } \\
\text { (iii) multidisciplinary teams } \\
\text { comprising r care } \\
\text { coordinators. }\end{array}$ & $\begin{array}{l}\text { (i) Expected Increasing of staff } \\
\text { motivation and positive } \\
\text { evaluations GPs (ii) Less waiting } \\
\text { times before receiving long-term } \\
\text { care support; (iii) better system } \\
\text { performance at no additional } \\
\text { cost. }\end{array}$ & $\begin{array}{l}\text { (i) fewer emergency admissions; } \\
\text { (ii) fewer bed days and shorter } \\
\text { hospital stays; (iii) fewer } \\
\text { residential home placements. }\end{array}$ \\
\hline $\begin{array}{l}\text { Althaus et al. } \\
\text { (2011) [26] }\end{array}$ & $\begin{array}{l}\text { Reducing } \\
\text { Frequent } \\
\text { Visits to the } \\
\text { Emergency } \\
\text { Department: } \\
\text { A Systematic } \\
\text { Review of } \\
\text { Interventions }\end{array}$ & $\begin{array}{l}\text { Systematic } \\
\text { review } \\
\text { (controlled } \\
\text { trials, } \\
\text { and without } \\
\text { control) }\end{array}$ & $\begin{array}{l}\text { Frequent hospital } \\
\text { ED users }\end{array}$ & $\begin{array}{l}\text { No specific definition. Most } \\
\text { interventions reviewed } \\
\text { included case management; } \\
\text { focus on coordination of } \\
\text { multi-disciplinary care by } \\
\text { case manager. }\end{array}$ & $\begin{array}{l}\text { Attenuate substance and drug use } \\
\text { and significantly decreasing } \\
\text { social problems }\end{array}$ & $\begin{array}{l}\text { The impact of all three frequent- } \\
\text { user interventions was modest. } \\
\text { Case management had the most } \\
\text { rigorous evidence based. }\end{array}$ \\
\hline $\begin{array}{l}\text { Ellen N \& } \\
\text { Emma P } \\
(2014)[47]\end{array}$ & $\begin{array}{l}\text { What is the } \\
\text { evidence on } \\
\text { the economic } \\
\text { impacts of } \\
\text { integrated } \\
\text { care? }\end{array}$ & $\begin{array}{l}\text { Review of } \\
\text { published } \\
\text { academic } \\
\text { literature on } \\
\text { the economic } \\
\text { impacts of } \\
\text { coordinated } \\
\text { services } \\
\text { approaches. } \\
\text {. }\end{array}$ & $\begin{array}{l}\text { Around } 963 \\
\text { references, focus } \\
\text { to three economic } \\
\text { outcomes: service } \\
\text { utilization, cost- } \\
\text { effectiveness and } \\
\text { quality outcomes. }\end{array}$ & $\begin{array}{l}\text { The case management was } \\
\text { most common concept. } \\
\text { Coordination of primary } \\
\text { care and community } \\
\text { services enhance the social } \\
\text { care services. }\end{array}$ & $\begin{array}{l}\text { Economic outcomes focused on: } \\
\text { (i) utilization of hospital services } \\
\text { through (re)admission rates, (ii) } \\
\text { length of stay and (iii) rate of } \\
\text { visits of emergency department. }\end{array}$ & $\begin{array}{l}\text { Very difficult to draw firm } \\
\text { conclusions because results } \\
\text { tended to be mixed. }\end{array}$ \\
\hline
\end{tabular}




\begin{tabular}{|c|c|c|c|c|c|c|}
\hline \multirow{2}{*}{ Author's } & \multirow{2}{*}{ Title } & \multirow{2}{*}{$\begin{array}{l}\text { Study } \\
\text { design }\end{array}$} & \multirow{2}{*}{$\begin{array}{c}\text { Targeted } \\
\text { populations }\end{array}$} & \multirow{2}{*}{$\begin{array}{l}\text { Definition of } \\
\text { integrated care }\end{array}$} & \multicolumn{2}{|c|}{ Outcome measures } \\
\hline & & & & & $\begin{array}{l}\text { Functional status } \\
\text { and outccomes }\end{array}$ & $\begin{array}{l}\text { Efficacy and client } \\
\text { satisfaction }\end{array}$ \\
\hline $\begin{array}{l}\text { De Bruin et al. } \\
\text { (2011) [31] }\end{array}$ & $\begin{array}{l}\text { Impact of } \\
\text { disease } \\
\text { management } \\
\text { programs on } \\
\text { healthcare } \\
\text { expenditures } \\
\text { for patients } \\
\text { with diabetes, } \\
\text { depression, } \\
\text { heart failure } \\
\text { or chronic } \\
\text { obstructive } \\
\text { pulmonary } \\
\text { disease: a } \\
\text { systematic } \\
\text { review of the } \\
\text { literature. }\end{array}$ & $\begin{array}{l}\text { Systematic } \\
\text { Pubmed } \\
\text { search }\end{array}$ & $\begin{array}{l}\text { Impact of disease } \\
\text { management } \\
\text { focus } \\
\text { healthcare } \\
\begin{array}{l}\text { expenditures } \\
\text { chronic and } \\
\text { model. care }\end{array}\end{array}$ & $\begin{array}{l}\text { Interventions focus on self } \\
\text { management } \\
\text { delivery sypport } \\
\text { support, } \\
\text { information system, healision- } \\
\text { care system, community } \\
\text { resources and policies. }\end{array}$ & $\begin{array}{l}\text { Disease management programs } \\
\text { for patients with diabetes, } \\
\text { depression, heart failure, and } \\
\text { COPD. Studies focus on cost- } \\
\text { saving with quality outcomes. }\end{array}$ & $\begin{array}{l}\text { Study shows that cost reduce } \\
\text { with quality outcomes. }\end{array}$ \\
\hline $\begin{array}{l}\text { Ouwens et } \\
\text { al. (2005) } \\
{[48]}\end{array}$ & $\begin{array}{l}\text { Integrated } \\
\text { care program } \\
\text { for } \\
\text { chronically ill } \\
\text { patients: a } \\
\text { review of } \\
\text { systematic } \\
\text { reviews }\end{array}$ & $\begin{array}{l}\text { Systematic } \\
\text { literature } \\
\text { review }\end{array}$ & $\begin{array}{l}\text { Medline and } \\
\text { Cochrane } \\
\text { databases using } \\
\text { medical subject } \\
\text { headings and } \\
\text { free text } \\
\text { searches } \\
\text { following very } \\
\text { specific terms. }\end{array}$ & $\begin{array}{l}\text { No explicit definitions: } \\
\text { integrated care program for } \\
\text { self management, clinical } \\
\text { follow up and case } \\
\text { management. }\end{array}$ & $\begin{array}{l}\text { Integrated care delivery seemed } \\
\text { to have definitive effects on the } \\
\text { quality of services. }\end{array}$ & $\begin{array}{l}\text { Cost interventions shows } \\
\text { positive trend and clients were } \\
\text { satisfied with quality services. }\end{array}$ \\
\hline $\begin{array}{l}\text { Gilbody et al. } \\
\text { (2006)[27] }\end{array}$ & $\begin{array}{l}\text { Costs and } \\
\text { consequences } \\
\text { of enhanced } \\
\text { primary care } \\
\text { for } \\
\text { depression: } \\
\text { systematic } \\
\text { review of } \\
\text { randomized } \\
\text { economic } \\
\text { evaluations. }\end{array}$ & $\begin{array}{l}\text { randomized } \\
\text { controlled } \\
\text { trials }\end{array}$ & $\begin{array}{l}11 \text { full economic } \\
\text { evaluations ( } 4757 \\
\text { patients). }\end{array}$ & $\begin{array}{l}\text { Enhanced primary care } \\
\text { focus to organizational } \\
\text { interventions. Majority of } \\
\text { studies set in the US } \\
\text { involved collaborative care } \\
\text { models linking primary and } \\
\text { specialist care.. }\end{array}$ & $\begin{array}{l}\text { Significant improvement in SCL } \\
\text { scores although not always } \\
\text { sustained. }\end{array}$ & $\begin{array}{l}\text { In conclusive evidence on } \\
\text { HRQoL }\end{array}$ \\
\hline
\end{tabular}




\begin{tabular}{|c|c|}
\hline $\begin{array}{c}\text { Integrated } \\
\text { Services and aged care }\end{array}$ & $\begin{array}{l}\text { (i)The integrated care has helped in the reduction of use of the use hospital services as follows: } 20.8 \% \text {, ED } \\
\text { visits } 27.9 \% \text { and in hospital admissions and } 19.2 \% \text { in bed days. Various studies on integrated care have } \\
\text { recommended the necessity to understand the integration process, user's individual needs, strengths, } \\
\text { weakness and impact of integrated service benefits [49-50]. (ii) Effective integrated care has a positive effect } \\
\text { on care delivery, especially on professional cognition and behaviour, which in turn affect the quality of care } \\
\text { [50] (iii) Integrated healthcare for the aged people can improve health, satisfaction and service utilization } \\
\text { outcomes [49]. (iv) The integrated care is used synonymously to refer to coordinated care and seamless care } \\
\text { that have one-stop services, which is most likely to produce polymorphous nature of integrated care itself. } \\
\text { The ultimate result is quality outcome if greater integration can be achieved [50]. (v) The integrated care } \\
\text { service is highly beneficial to multi-morbid and severe chronic disease patients and the elderly. Integration } \\
\text { is exposed to improving of coordination, quality, efficiency and controlling of cost [49-50]. (vi) There are } \\
\text { three fundamental issues that have been considered for improving and integrating the care of older people } \\
\text { of Australia: (a) adopt a strong person-centred approach (b) better understand the complexity of older } \\
\text { people's health care needs and (c) improving integration within existing system59. (vii) Strong leadership, } \\
\text { collaboration among key stakeholders; good infrastructure and effective exchange and utilization of } \\
\text { information between sectors' collaborating groups, and care providers are important to serve elderly over } \\
\text { time [47-49] (viii) Various studies and evidences have shown that integrated health care contributes to a } \\
\text { cost-efficient and quality health system through streamlined care of patients, efficient use of resources, a } \\
\text { better cover of patients and improved patient safety [50]. }\end{array}$ \\
\hline Costs-Effectiv & $\begin{array}{l}\text { (i) Timely service delivery, coordinated medical care, improved care coordination can save upto 5\%-10\% } \\
\text { of costs in the integrated care system. However, the cost benefits and quality of care depend on physician } \\
\text { and hospital management relationships and market dynamics [48]. (ii) There is no significant difference in } \\
\text { utilization and costs of the emergency department visit in integrated care, but satisfaction and quality of care } \\
\text { may improve with modest costs [49]. (iii) Integrated care management and coordinated service enhance the } \\
\text { quality outcomes and reduce Medicaid clinical costs at a variety of settings [34]. (iv) Integrated primary care } \\
\text { in the appropriate setting can meet upto } 90-95 \% \text { of the health needs, produce better health outcomes and } \\
\text { improved cost-effectiveness [50]. (v) The integrated care has a triple aim:to better health outcomes, to } \\
\text { better care, and to lower costs. Integrated patient-centered healthcare saved the state about } \$ 60 \text { million in } \\
\text { Medicaid costs in } 2003 \text { and the saving increased to } \$ 154 \text { million in } 2007 \text { in The USA [49]. (vi). In integrating } \\
\text { and coordinating services frequent hospital ED users are cost-effective and led to improved clinical and } \\
\text { social outcomes [46-49]. (vii) Cost savings associated with structured home-based, nurse-led health } \\
\text { promotion for older people at risk of hospital or care home admission [50] }\end{array}$ \\
\hline Quality of care & $\begin{array}{l}\text { (i) Enhancing care continuity and coordination are two important components of integrated healthcare and } \\
\text { it seems to provide better quality of care [38], reduces lengths of stay and medication errors and number of } \\
\text { office visits [49]. (ii) Functional integration is more significant than merely structural or financial integration } \\
\text { as a determinant of quality outcomes of chronic integrated care systems [50] (iii) The vast majority of studies } \\
\text { related to integrated service have shown that there were positive effects on quality of care; however, } \\
\text { accurately measuring the performance of the health system, cost and quality of outcomes of the system are } \\
\text { very difficult [36]. (iv) Integrated care highlights the integration of care across service providers, setting of } \\
\text { services and degree of coordination, which depends on the growing burden of chronic disease in a defined } \\
\text { health sector [49-50]. }\end{array}$ \\
\hline
\end{tabular}




\section{APPENDIX-1: TABLE-SEARCHING SUMMARY}

Number of Total Articles \& Reports Found [2001-2017]

\begin{tabular}{|c|c|c|c|c|c|c|c|}
\hline \multicolumn{3}{|l|}{ Searched Database } & \multicolumn{5}{|c|}{ Search terms } \\
\hline Eight data sources & Field \& Access & $\begin{array}{l}\text { Document } \\
\text { Type }\end{array}$ & $\begin{array}{l}\text { Integrated } \\
\text { healthcare } \\
\text { for the older } \\
\text { people }\end{array}$ & Cost & $\begin{array}{l}\text { Quality } \\
\text { care }\end{array}$ & $\begin{array}{l}\text { Cost \& } \\
\text { Quality } \\
\text { care }\end{array}$ & $\begin{array}{l}\text { Cost, } \\
\text { quality \& } \\
\text { outcomes }\end{array}$ \\
\hline Springer Link & All & Journals & 29103 & 3763 & 654 & 307 & 138 \\
\hline Science Direct & All & Journals & 23225 & 2877 & 459 & 98 & 78 \\
\hline Wiley Online Library & All & Journals & 28581 & 1857 & 1234 & 133 & 79 \\
\hline Medline (PubMed) & All & Journals & 6385 & 476 & 112 & 73 & 66 \\
\hline CINAHL & All & Journals & 231 & 72 & 23 & 21 & 13 \\
\hline Psyclnfo & All & Journals & 112 & 68 & 25 & 19 & 11 \\
\hline Web of Science (SCl,SSCl, $\mathrm{HCl})$ & All & Journals & 4273 & 243 & 75 & 21 & 15 \\
\hline Google Scholar & All & All & 18000 & 7684 & 4320 & 3210 & 2846 \\
\hline \multicolumn{3}{|l|}{ Total } & 109910 & 17040 & 6902 & 3882 & 3246 \\
\hline
\end{tabular}

